\title{
AKSJOLOGIA WOLNOŚCI MEDIÓW W ŚWIETLE PRAC WYSOKIEGO PRZEDSTAWICIELA OBWE DO SPRAW WOLNOŚCI MEDIÓW
}

\begin{abstract}
Wolność mediów, wolność wypowiedzi i swobody w przekazywaniu informacji stanowi jeden z priorytetów OBWE. Autor niniejszego artykułu poddaje analizie działalność utworzonej w 1997 r. instytucji Przedstawiciela OBWE ds. Wolności Mediów. Instytucja ta jest odpowiedzią na obserwowane w wielu państwach narastające dążenia do ograniczenia swobody, a także niezależności mediów.

Główne zadanie Przedstawiciela OBWE ds. Wolności Mediów polega na monitoringu tych obszarów z zakresu wolności mediów, które wymagają wsparcia w państwach uczestniczących OBWE. Dlatego bardzo ważną funkcją jest niesienie pomocy tym państwom przez wnikliwą obserwację oraz wydawanie opinii na temat praktyk dotyczących prześladowania wolności wypowiedzi. Przedstawiciel otrzymuje informację o sytuacji mediów z różnych źródeł - m.in. państw uczestniczących, organizacji medialnych oraz organizacji pozarządowych.

Przedstawiciel ściśle współpracuje ze Stałą Radą, z Biurem Instytucji Demokratycznych i Praw Człowieka, Wysokim Komisarzem ds. Mniejszości Narodowych oraz w stosownych przypadkach $\mathrm{z}$ innymi organami OBWE, a także z krajowymi i międzynarodowymi stowarzyszeniami mediów. Przedstawiciel ds. Wolności Mediów podejmuje tym samym liczne działania i uczestniczy w projektach, które są związane z wolnością słowa i wolnością mediów. Bierze również udział w wykładach oraz dyskusjach na takie tematy, jak wolność prasy, radia, telewizji i Internetu. Przedstawiciel skupia szczególną uwagę na bezpieczeństwu dziennikarzy, wolności słowa i podstawowych prawach człowieka.
\end{abstract}

Slowa kluczowe: wolność mediów, OBWE, Przedstawiciel ds. Wolności Mediów, bezpieczeństwo dziennikarzy

W wielu krajach rozwój mediów i nowych technologii traktowany jest jako rodzaj zagrożenia, który powinien być kontrolowany ${ }^{2}$. Tymczasem nie istnieje bezpieczny przepływ informacji, jeśli nie ma bezpiecznego społeczeństwa i odwrotnie - nie można mówić o bezpiecznym społeczeństwie, jeżeli nie ma wolnych mediów i swobodnego przepływu informacji.

Rozwinięte media są podstawą demokratycznych społeczeństw³ ${ }^{3}$ Wartość ta eksponowana jest między innymi przez regionalne organizacje międzynarodowe: Radę Europy (RE) ${ }^{4}$, Unię Europejską (UE) ${ }^{5}$ i Organizację Bezpieczeństwa i Współpracy w

\footnotetext{
${ }^{1}$ Mgr Adam Kruk, Wydział Zarządzania i Administracji, Uniwersytet Jana Kochanowskiego w Kielcach, e-mail: Adam.Kruk@tvp.pl

${ }^{2}$ Zob. M.E. Price, Free Expression, Globalism and the New Strategic Communication, New York 2015, s. 49.

${ }^{3}$ Zob. H. Żur, Systemy demokratyczne a informacja, „Wiadomości Statystyczne” 2003/1, s. 73-77. Por. R. Wacks, Privacy and the Media Freedom, Oxford 2013, s. 34.

${ }^{4}$ Zob. A. Jaskiernia, Rada Europy a problemy mediów masowych, Warszawa 2002, s. 37.
} 
Europie $(\mathrm{OBWE})^{6}$. Organizacja Bezpieczeństwa i Współpracy w Europie monitoruje rozwój mediów w państwach uczestniczących. Monitoring mediów odgrywa istotną rolę ${ }^{7}$ : obejmuje przegląd prawodawstwa dotyczącego mediów, a także wypadki, w których dziennikarze są ścigani za ich działalność zawodową lub są ofiarami molestowania. Rodzi się więc pytanie, w jakim zakresie i za pomocą jakich narzędzi OBWE formułuje standardy dotyczące wolności mediów i w jaki sposób oddziałuje na państwa członkowskie.

Wolność mediów, wolność wypowiedzi, jak i swobody w przekazywaniu informacji stanowią jeden z priorytetów OBWE. Wymienione obszary należą niewątpliwie do tych, które wymagają monitorowania oraz wsparcia w wielu krajach. Jednocześnie należy podkreślić, że ich zaniedbanie rodzi konsekwencję braku możliwości rozwoju społeczeństw w dzisiejszym świecie, gdyż przekaz wiedzy, zagadnień kulturowych oraz powszechnej informacji stanowi nieodłączną jego część ${ }^{8}$. W ramach OBWE funkcjonuje wiele instytucji pomocniczych. Na szczególną uwagę zasługuje utworzona w $1997 \mathrm{r}$. instytucja Przedstawiciela OBWE ds. Wolności Mediów (Representative on Freedom of the Media), ${ }^{9}$. Instytucja ta jest odpowiedzią na obserwowane w wielu państwach narastające dążenia do ograniczenia swobody, a także niezależności mediów. Główny sens jego działania opiera się na przekonaniu, że media pełnią istotną funkcję $\mathrm{w}$ budowaniu społeczeństwa obywatelskiego, kontrolując poczynania władz, w tym w sferze praw człowieka. Przedstawiciel odgrywa rolę tak zwanego watchdog, czyli organu monitorującego media ${ }^{10}$.

Główną podstawę do działania Przedstawiciela stanowi niewątpliwie „Dokument Spotkania Kopenhaskiego Konferencji w Sprawie Ludzkiego Wymiaru KBWE"11, a dokładnie punkt 10 mówiący o ,poszanowaniu prawa każdego człowieka, indywidualnie lub wespół z innymi, do swobody zdobywania, otrzymywania i przekazywania poglądów $\mathrm{i}$ informacji dotyczących praw człowieka i podstawowych wolności, włączając $\mathrm{w}$ to prawo do rozpowszechniania i publikowania takich poglądów i informacji”. Istotne zapisy tego dokumentu odnajdujemy także w punkcie 26 , w którym mowa o wolności przepływu informacji w takich obszarach, jak dziennikarstwo, niezawisłe środki przekazu i życie intelektualne oraz kulturalne.

Pierwszym Przedstawicielem ds. Wolności Mediów OBWE był niemiecki polityk Freimut Duve, urząd piastował do 2003 r. Następnie urząd zajmował Miklós Haraszti, węgierski pisarz, dziennikarz, prawnik zajmujący się prawami człowieka oraz profesor

\footnotetext{
${ }^{5}$ Zob. C. Mik, Media masowe w europejskim prawie wspólnotowym, Torun 1999, s. 57.

${ }^{6}$ Zob. Human Rights and a Changing Media Landscape, Strasbourg 2011, s. 7.

${ }^{7}$ Zob. A. Jaskiernia, Metody badawcze europejskich standardów demokratycznych $w$ obszarze mediów masowych, „Przegląd Europejski” 2011/1, s. 13-28.

${ }^{8}$ Zob. J. Skowron, Ocena niezależności funkcjonowania mediów w latach 2008-2011 przez Przedstawiciela do Spraw Wolności Mediów OBWE, [w:] Efektywność europejskiego systemu ochrony praw człowieka, t. I: Efektywność mechanizmów ochrony praw człowieka Rady Europy, Unii Europejskiej i OBWE, red. J. Jaskiernia, Torun 2012, s. 707.

${ }^{9}$ Mandate of the OSCE Representation on Freedom of the Media, Permanent Council Decision No. 193, Organization for Security and Co-operation in Europe, 5 November 1997.

${ }^{10}$ Zob. D. Mijatović, The Main Challenges of the OSCE Representative on Freedom of the Media, „Security and Human Rights” 2013/3-4, s. 327.

${ }^{11}$ Document of the Copenhagen Meeting of the Conference on the Human Dimension of the OSCE, OSCE, 29 June 1990, www.osce.org/odihr/elections/14304?download=true (dostęp: 19.02.2015).
} 
akademicki do 2010 r. Obecnie funkcję Przedstawiciela OBWE ds. Wolności Mediów pełni Dunja Mijatović z Bośni i Hercegowiny ${ }^{12}$, ekspert z zakresu regulacji prawa medialnego ${ }^{13}$. Kadencja Przedstawiciela wynosi trzy lata, natomiast główna siedziba Przedstawiciela mieści się w Wiedniu.

Przedstawiciel OBWE ds. Wolności Mediów jest najmłodszą instytucją OBWE ${ }^{14}$, zajmującą się kontrolą oraz przestrzeganiem międzynarodowych standardów w zakresie wolności środków masowego przekazu w państwach przynależących do Organizacji ${ }^{15}$. W związku z tym podstawowym zadaniem Przedstawiciela ds. Wolności Mediów jest udzielanie pomocy mediom. W tym celu współpracuje on ze wszystkimi krajami wchodzącymi w skład wspólnoty. Interesuje się każdą sytuacją będącą przejawem nietolerancji, rasizmu, nacjonalizmu bądź agresji ze strony państw - członków OBWE. Tylko w 2011 r. Przedstawiciel interweniował aż 140 razy w sprawach dotyczących mediów ${ }^{16}$.

Zaangażowanie Przedstawiciela może przybierać różne formy, począwszy od interwencji za kulisami - „,cicha dyplomacja" ${ }^{17}$ lub poprzez bezpośrednie kontakty z ministrami spraw zagranicznych państw członkowskich $w$ celu wyjaśnienia niepokojących go wydarzeń, związanych między innymi z nadużywaniem przez władze przepisów o zniesławieniu czy wprowadzeniem zmian w ustawodawstwie dotyczącym mediów, niezgodnych ze standardami demokratycznymi. Ponadto pozostaje on w bezpośrednim kontakcie z Przewodniczącym OBWE oraz Stałą Radą, której składa okresowe sprawozdania ze swojej działalności.

Przedstawiciel ds. Wolności Mediów uświadamia władzom państw, że media nie są ich prywatną własnością, a dziennikarze mają prawo do kontroli osób publicznych, które zostały wybrane przez społeczeństwo do jego reprezentacji. Przemoc wobec dziennikarzy jest równoznaczna ze stosowaniem jej przeciwko społeczeństwu i demokracji ${ }^{18}$.

Przedstawiciel poddaje wnikliwej obserwacji i komentuje stosowane praktyki prawne dotyczące prześladowania wolnego słowa ${ }^{19}$. Dotyczy to przede wszystkim nieprzyjaznych dla wolności mediów sankcji za zniesławienie, pomówienie czy zniewagę. Szczegółowo

\footnotetext{
${ }^{12}$ Decision No. 1/13, Extension of the Mandate of the OSCE Representative on Freedom of the Media, Organization for Security and Co-operation in Europe Ministerial Council, MC. DEC/1/13, 6 March 2013.

${ }^{13} \mathrm{http}: / /$ www.osce.org/fom (dostęp: 17.02.2015).

${ }^{14}$ Zob. K. Mrozik, Przedstawiciel ds. Wolności Mediów Organizacji Bezpieczeństwa $i$ Wspótpracy w Europie, [w:] Efektywność..., s. 694-706.

${ }^{15}$ A. Florczak, Organizacje regionalne o charakterze ogólnym, [w:] Organizacje $w$ stosunkach międzynarodowych. Istota - mechanizmy działania - zasięg, red. T. Łoś-Nowak, Wrocław 2009, s. 136.

${ }^{16}$ Zob. Why Free Media Matters, OSCE/ The Representative on Freedom on the Media, Vienna 2012, s. 5.

${ }^{17}$ Zob. The Representative on Freedom of the Media, Why Free Media Matters - OSCE, OSCE 2012, http://www.osce.org/fom/31230?download=true (dostęp: 14.02.2015).

${ }^{18}$ Zob. Przedstawiciel ds. Wolności Mediów: Ataki na dziennikarzy w Hiszpanii sa nie do przyjęcia, http://www.osce.org/fom/116993 (dostęp: 17.02.2015).

${ }^{19}$ Por. Commitments. Freedom of the Media. Freedom of the Expression. Free Flow of Information. Conference on Security and Co-operation in Europe (CSCE) and Organization for Security and Cooperation in Europe (OSCE), 1975-2012, wyd. 2, OSCE, Representative on Freedom of the Media, Vienna 2013, s. 56.
} 
sprawdza zakres „tematów tabu”, takich jak zakaz pisania o niektórych osobach czy wydarzeniach oraz śledzi procesy dziennikarzy, którzy zostali oskarżeni na podstawie sfabrykowanych zarzutów i dowodów, oraz staje w ich obronie ${ }^{20}$.

Przedstawiciel uzyskał status obserwatora w Komitecie ds. Spraw Mediów Masowych Rady Europy (CDMM), który w 2005 r. został przekształcony w Komitet Zarządzający ds. Mediów i Nowych Technologii Komunikacyjnych (CDMC). Komitet składa się z ekspertów wydelegowanych przez państwa członkowskie Rady Europy. Głównym celem Komitetu jest rozwijanie współpracy miedzy państwami członkowskimi Rady Europy w dziedzinie mediów masowych oraz wypracowywanie odpowiednich środków polityki europejskiej ${ }^{21}$.

Warto przeanalizować najważniejsze kierunki aktywności Przedstawiciela, aby poznać priorytety jego działalności. Podczas wizyty na Białorusi w 2013 r. Dunja Mijatović spotkała się z przedstawicielami reżimowego stowarzyszenia białoruskich dziennikarzy. $\mathrm{Na}$ konferencji prasowej zaapelowała do władz o zreformowanie ustawy medialnej i wezwała do natychmiastowego zaprzestania aresztowań dziennikarzy: „Jestem zdecydowanie przekonana, że warunkiem jakichkolwiek pozytywnych zmian w sferze wolności mediów na Białorusi jest natychmiastowe zaprzestanie krótkoterminowych aresztowań dziennikarzy. W ostatnim czasie było ich 60 - oznajmiła Mijatović i dodała Należy też rozpocząc liberalizację i reformę przestarzałej ustawy o mediach i wszystkich innych ustaw mających związek z wolnością mediów i Internetu"22. Podkreśliła też, że „Należy zezwolić na krytyczne, prowokacyjne głosy w społeczeństwie, choćby było to bardzo niewygodne, a czasem drażliwe czy bolesne. Jeśli komuś to nie odpowiada, może zwrócić się do sądu. Ale żadnego dziennikarza nie wolno za to wsadzać do więzienia ani nękać. Taka jest cena demokracji" ${ }^{23}$.

Przedstawicielka OBWE odnotowała także pozytywne wydarzenia na Białorusi w sferze wolności mediów. Za jedno z nich uznała umorzenie sprawy dziennikarza „Gazety Wyborczej" Andrzeja Poczobuta oskarżonego o zniesławienie Aleksandra Łukaszenki. Według Mijatović pozytywnym zjawiskiem jest również coraz szerszy dostęp do Internetu na Białorusi, który jej zdaniem powinien być coraz bardziej powszechny ${ }^{24}$.

W 2014 r. Dunja Mijatović wyraziła głębokie zaniepokojenie z powodu zastraszania i przemocy policyjnej wobec dziennikarzy relacjonujących demonstracje, które odbyły się w Madrycie 29 marca 2014 r. Według doniesień mediów i stowarzyszeń zawodowych, dziennikarze byli wyraźnie atakowani przez policjantów. Policja utrudniała dziennikarzom fotografowanie i zbieranie informacji.

„Każda próba zastraszenia lub atakowania dziennikarzy jest oczywistym naruszeniem prawa do wolności mediów i nie może być tolerowana - powiedziała Mijatović dla portalu osce.org. Dodała również - Wzywam władze hiszpańskie do prawidłowego zabezpieczenia i poprawy bezpieczeństwa dziennikarzy relacjonujących podczas

\footnotetext{
${ }^{20}$ Zob. W. Horsley, Safety of Journalist Guidebook, wyd. 2, Office of the Representative on Freedom of the Media, Vienna 2014, s. 23-29.

${ }^{21}$ Zob. A. Jaskiernia, Rada Europy..., s. 96.

${ }^{22}$ OSCE Representative Welcomes Enhanced Media Freedom Dialogue with Belorus, urgens Improvements, www.osce.org/fom/102341 (dostęp: 09.04.2015).

${ }^{23}$ Ibidem.

${ }^{24}$ Ibidem.
} 
demonstracji publicznych"25. Przedstawicielka OBWE ds. wolności mediów podkreśliła konieczność dokładnego zbadania ataków na dziennikarzy z 2 marca 2014 r.

„Mijatović wielokrotnie podkreślała znaczenie bezpieczeństwa dziennikarzy, ponieważ stanowi ono podstawowy warunek dla skutecznego i pełnego korzystania $z$ prawa do wolności informacji, dla wolnych i demokratycznych mediów" - czytamy na osce.org.

Ochrona bezpieczeństwa dziennikarzy stanowi niewątpliwie jeden z głównych celów Przedstawiciela. W tym celu opracował specjalny przewodnik ${ }^{26}$, w którym opisuje zobowiązania w związku $\mathrm{z}$ członkostwem w OBWE dotyczące dziennikarzy. Zobowiązania te dotyczą zapewnienia bezpieczeństwa i wolności mediów. Przewodnik został stworzony w odpowiedzi na wzrost przypadków zastraszania i represji wobec dziennikarzy. Jest to publikacja mówiąca o ukierunkowanej przemocy wobec dziennikarzy i wzroście kultury bezkarności. Niestety zjawisko to ma wpływ na osłabienie standardów demokracji i rządów prawa ${ }^{27}$.

Istotnym zadaniem Przedstawiciela ds. Wolności Mediów jest wspieranie pluralizmu $^{28}$, który ma zasadnicze znaczenie dla zapewnienia obywatelom podejmowania świadomych decyzji szczególnie w czasie wyborów. Zasada pluralizmu wynika między innymi z art. 11 Karty Praw Podstawowych UE, w myśl którego „szanuje się wolność i pluralizm mediów". Nie odnosi się ona wyłącznie do pluralizmu własności mediów, ale również do różnorodności przekazywanych informacji ${ }^{29}$. Zgodnie $\mathrm{z}$ definicją pluralizmu, sformułowaną w 2005 r. przez Europejską Komisję na Rzecz Demokracji przez Prawo (Komisję Wenecką), „Pluralizm mediów jest osiągnięty, gdy istnieje wiele autonomicznych i niezależnych mediów na poziomie narodowym, regionalnym i lokalnym, które zapewniają szeroki wybór treści odzwierciedlających różne poglądy polityczne i kulturalne ${ }^{30 \%}$. Na wielowymiarowość pluralizmu zwróciła również uwagę Komisja Europejska w trzystopniowej analizie opracowanej w styczniu 2007 r. ${ }^{31}$, zgodnie z nią pluralizm wiąże się z dbaniem o różnorodność geopolityczną i kulturową. Oznacza to konieczność przedstawiania zróżnicowanych poglądów, ujęć i wieloaspektowego ukazywania spraw w celu ich realizacji tak zwanego communication wright odbiorcy, dającego mu prawo do uzyskania pełnej, uczciwej informacji oraz możliwość usłyszenia i porównania wielu opinii. Dlatego ważnym celem działalności Przedstawiciela jest

25 Attacks Against Journalists in Spain are Unacceptable, says OSCE Media Freedom Representative, Toronto, 1 April 2014, www.osce.org/fom/116993 (dostęp: 30.04.2015).

${ }^{26}$ Zob. OSCE Safety of Jurnalist Guidebook: Secondo Editiopn published in response to Rising Concerns over Anti-media Violence and Harassment, www.aej.org/page.asp?p_id=448 (dostęp: 12.02.2015).

${ }^{27}$ Zob. P. Pasionek, Demokracja a media, Lublin 2008, s. 143-159.

${ }^{28}$ Szerzej: The Representative on Freedom of the Media, Pluralism and Internet Governance, 13th Central Asia Media Conference Duszanbe, Tajikistan 29-30 Novembe 2011, Organization for Security and Co-operation in Europe 2012.

${ }^{29}$ Zob. E. Komorek, Media Pluralism and European Law, Alphen aan der Rijn 2013, s. 112.

${ }^{30}$ Zob. Sprawozdanie z 38 posiedzenia Europejskiej Platformy Organów Regulacyjnych, Wilno, $2-4$ października 2013

www.krrit.gov.pl/Data/Files/_public/Portals/0/konferencje/sprawozdania/2013/sprawozdanie_wilno 2.pdf (dostęp: 4.04.2015).

${ }^{31}$ Commission three - step approach for advancing the debate on media pluralism within in European Union, IP/07/52. 
wspieranie mediów i utrwalanie w przekonaniu o słuszności ich wysiłków zmierzających do poprawy ich sytuacji ${ }^{32}$.

Zdaniem Przedstawiciela wszystkie próby ograniczenia pluralizmu mediów zarówno tych tradycyjnych, jak i internetowych muszą być zwalczane ${ }^{33}$. Dlatego rolą rządów w każdym z państw członkowskich OBWE jest pozbywanie się „niezdrowych” przepisów dotyczących wolności słowa ${ }^{34}$. Wielu nadawców publicznych stoi przed wyzwaniami zarówno politycznymi, jak i finansowymi, które sprawiają, że trudno im utrzymać swoją niezależność, co jest kluczowe dla każdego społeczeństwa demokratycznego. Ograniczenia dotyczące pluralizmu mediów były przedmiotem wystąpień Przedstawiciela podczas wielu wystapień. Ich efektem stały się liczne wartościowe publikacje, na przykład Wplyw koncentracji mediów na profesjonalnego dziennikarza ${ }^{35}$.

Obowiązek ochrony wolności poglądów, słowa i dostępu do informacji oraz wolności mediów jest przede wszystkim obowiązkiem państw członkowskich UE, ponieważ wartości te są gwarantowane również w ich konstytucjach i prawie. Wziąwszy to pod uwagę, w wypadku poważnego zagrożenia wolności i pluralizmu mediów w którymkolwiek z państw członkowskich na podstawie Traktatów i Karty Praw Podstawowych Unia Europejska powinna, przy wsparciu takich organów jak Przedstawiciel ds. Wolności Mediów OBWE, a zwłaszcza dzięki analizie wynikającej z jego doświadczeń, przedsięwziąć działania mające na celu ochronę europejskiego systemu demokratycznego i pluralistycznego oraz praw obywateli. Parlament Europejski nieustannie wspiera taką interpretację Traktatów i Karty Praw Podstawowych, a doktryna określa to podejście jako „odwróconą doktrynę Solange” w dążeniu do ochrony istoty praw podstawowych oraz obywateli europejskich gwarantowanych w art. 2 Traktatu o Unii Europejskiej poprzez środki prawne skierowane przeciwko tym państwom członkowskim, które naruszają te prawa na poziomie wewnętrznym i europejskim ${ }^{36}$.

Wolność słowa łączona jest niekiedy $\mathrm{z}$ mową nienawiści - hate speech. We współczesnym świecie mowa nienawiści powszechnie uważana jest za poważne naruszenie praw człowieka. Konflikt pomiędzy wolnością słowa a mową nienawiści pozostaje jednym $\mathrm{z}$ najbardziej problematycznych obszarów w zakresie funkcjonowania demokratycznego państwa i społeczeństwa ${ }^{37}$. W tym zakresie Przedstawiciel OBWE ds. Wolności Mediów nie ma żadnych uprawnień sądowniczych, a jedynie opiera swoje działania na monitoringu, nie może więc sankcjonować „nienawistnych słów” i nie monitoruje mediów pod tym kątem. Zamiast tego promuje wysokiej jakości dziennikarstwo.

\footnotetext{
${ }^{32}$ Zob. R. Fawn, International Organizations and Internal Conditionality: Making Norms Matter, New York 2013, s. 188.

${ }^{33}$ Por. E. Brogi, A. Dobreva, P.L. Parcu, Freedom of the Media in Western Balkans, European Parliament, EESC, Brussels 2014, s. 5.

${ }^{34}$ Por. Medias and European Diversity, red. L. Soproni, I, Horga, Brussels 2012.

35 The Representative on Freedom of the Media, The Impact of Media Concentration on Professional Journalist, OSCE, Vienna 2003.

36 Doktryna wspiera istotę tego poglądu, zob. C. Antpöhler, A.V. Bogdandy, J. Dickschen, S. Hentrei, M. Kottmann, M. Smrkolj, Reverse Solange - Protecting the essence of Fundamental Rights Against EU Member States, „Common Market Law Review” 2012/2, s. 489-519.

${ }^{37}$ Zob. A. Biłgorajski, Mowa nienawiści vs. Wolność słowa (głos w dyskusji), [w:] Mowa nienawiści a wolność słowa. Aspekty prawne $i$ społeczne, red. A. Bodnar, A. Gliszczyńska-Grabias, R. Wieruszewski, M. Wyrzykowski, Warszawa 2010, s. 190-196.
} 
Samoregulacja i promowanie wysokiej jakości dziennikarstwa to czynniki, które wzmacniają wolność mediów ${ }^{38}$. Ale ,jakość" nie powinna być warunkiem wstępnym dla wolności, tylko bowiem całkiem wolna prasa może być w pełni odpowiedzialna. Przedstawiciel wprowadził i wdrożył wiele inicjatyw mających na celu wspieranie rozwoju samoregulacji mediów ${ }^{39}$ i zwiększenia jakości dziennikarstwa, wszystko to po to, aby poprawić ogólną sytuację wolności mediów na obszarze OBWE.

Według Przedstawiciela kryzys wysokiej jakości mediów może oznaczać kryzys demokracji. Przedstawiciel stawia tym samym znak równości pomiędzy jakością informacji przekazywanej przez media a jakością demokracji. Wspiera zatem dziennikarzy, którzy chcą się zjednoczyć $w$ wysiłkach na rzecz podnoszenia i upowszechniania standardów zawodowych i etycznych dziennikarstwa, a co za tym idzie - przyczynić się do poprawy ogólnej sytuacji w zakresie wolności mediów na obszarze OBWE.

Próby ograniczenia wolności słowa przez narzucanie ustawodawstwo państw członkowskich nieprzemyślanych przepisów nie są niestety zjawiskiem nowym w regionie OBWE. Chcąc pomóc tym państwom, Przedstawiciel od 1997 r. zlecił ponad 50 opinii prawnych na temat przepisów dotyczących mediów. Przedstawiciel starał się tym samym zmieniać realia prawne i faktyczne w całym regionie OBWE.

Dostęp do informacji jest jednym z najważniejszych uprawnień prawnych dotyczących działalności dziennikarskiej. Bez możliwości dostępu dziennikarz informacyjny nie może odpowiednio funkcjonować i w prawidłowy sposób ponosić odpowiedzialność za swoje działania. Pomimo tak istotnego znaczenia dostępu do informacji dla demokracji władze w niektórych częściach regionu OBWE niechętnie dzielą się informacjami z przedstawicielami mediów i społeczeństwem w ogóle ${ }^{40}$. To jest trudne do pogodzenia $\mathrm{z}$ zobowiązaniami OBWE dotyczącymi dostępu do informacji ${ }^{41}$. Ponieważ urząd Przedstawiciela ds. Wolności Mediów został stworzony, aby pomagać państwom uczestniczącym w wypełnianiu ich zobowiązań względem OBWE, Przedstawiciel opowiada się za bardziej liberalnym dostępem do polityki informacyjnej ${ }^{42}$.

Informacja będąca $\mathrm{w}$ dyspozycji dziennikarzy w pewnych warunkach i z pewnych przyczyn musi niekiedy przybierać charakter poufny. Obecna Przedstawiciel Dunja Mijatović uznała, że nie do przyjęcia są takie działania, do jakich doszło w redakcji „Wprost". Zaznaczyła, iż takiego typu działania mają negatywny wpływ na dziennikarstwo śledcze i tłumią wolność mediów. Wezwała tym samym polskie władze

\footnotetext{
${ }^{38}$ Zob. Journalist Education - Improvement of the Quality of Education and New Technologies, $6^{\text {th }}$ South Caucasus Media Conference, Tbilisi, Georgia, 19-20 November 2009, OSCE/The Representative on Freedom of the Media, Vienna 2010, s. 23-34.

${ }^{39}$ Zob. The Online Media Self-Regulation Guidebook, OSCE/The Representative on Freedom of the Media, Vienna 2013, s. 74-85.

40 Zob. OSCE Safety of Journalists Guidebook, OSCE/The Representative on Freedom of the Media, Vienna 2011, s. 24-27.

${ }^{41}$ Por. Commitments Freedom of the Media. Freedom of Expression, Free Flow of Information, Conference on Security and Co-operation in Europe (CSCE) and Organization for Security and Cooperation in Europe (OSCE), 1975-2012, OSCE/The Representative on Freedom of the Media, Vienna 2012, s. 10-47.

${ }^{42}$ Zob. Access to Information and New Technologies, 12th Central Asia Media Conference Dushanbe, Tajikistan 25-26 May 2010, OSCE/The Representative on Freedom of the Media, Vienna 2012, s. 25.
} 
do poszanowania wolności mediów, stwierdzając, że ,prawa dziennikarzy do ochrony źródeł informacji poufnych muszą być chronione, a podstawowa rola mediów w każdej demokracji musi być zapewniona" ${ }^{\text {"43 }}$.

Dunja Mijatović podkreśliła również, że tajemnica dziennikarska stanowi jeden z fundamentów społeczeństwa obywatelskiego. Przypomniała, że podobne działania służb specjalnych w przeszłości przeprowadzono w redakcjach znanych zagranicznych pism w innych krajach Europy. Jednak w tych przypadkach nie chodziło o to, żeby pognębić prasę i zamknąć jej usta, lecz o to, żeby zdobyć określony dowód.

Dunja Mijatović zdecydowanie potępiła również atak terrorystyczny na francuski magazyn satyryczny Charlie Hebdo w Paryżu, stwierdzając, że ,jest to bezprecedensowy atak na wolność mediów i wolność wypowiedzi"44.

Przedstawiciel ds. Wolności Mediów bierze również udział w opracowywaniu dokumentów związanych $\mathrm{z}$ wolnością mediów w Internecie ${ }^{45}$. Urząd zainicjował cykl konferencji na temat wolności Internetu na początku 2000 r. $^{46}$, czego efektem była Wspólna deklaracja $w$ sprawie wolności słowa i Internetu ${ }^{47}$, podpisana przez Specjalnego Sprawozdawcę ONZ ds. Promocji oraz Ochrony Prawa do Wolności Wyrażania Opinii oraz Wolności Wypowiedzi; Przedstawiciela OBWE ds. Wolności Mediów; Specjalnego Sprawozdawcę OPA ds. Wolności Słowa oraz Specjalnego Sprawozdawcę Afrykańskiej Komisji Praw Człowieka i Ludów ds. Wolności Wypowiedzi i Dostępu do Informacji.

Podczas corocznej konferencji OBWE Human Dimention Implementation Meeting, która odbyła się 26 września 2011 r. W Warszawie, w poszczególnych panelach głos zabrała między innymi Dujna Mijatović ${ }^{48}$. Podkreśliła przede wszystkim wpływ rozwoju Internetu na wolność wypowiedzi. Mijatović zaznaczyła, że w krajach, które monitoruje, dostrzega coraz większe restrykcje w korzystaniu z sieci. Wysiłek wielu krajów, aby uciszyć niewygodne głosy, zdaniem Przedstawicielki, skupia się teraz głównie na blokowaniu $\mathrm{i}$ filtrowaniu treści on-line pod pretekstem walki $\mathrm{z}$ terroryzmem czy pornografią dziecięcą w Internecie ${ }^{49}$. To ważny wniosek w kontekście trwających od kilku lat na szczeblu europejskim prac nad dyrektywą unijną mającą wprowadzić mechanizm blokowania sieci właśnie ze zwalczaniem serwisów pedofilskich. Przykład krajów, takich

43 OBWE wzywa polskie władze do szanowania wolności stowa, http://www.polskieradio.pl/5/3/Artykul/1156706,OBWE-wzywa-polskie-wladze-do-szanowaniawolnosci-slowa (dostęp: 18.02.2015).

${ }^{44}$ Publiczne oświadczenie Przedstawiciela OBWE ds. Wolności Mediów w sprawie ataku na Charlie Hebdo jest dostępne na stronie: www.osce.org/fom/133526.

${ }^{45}$ Szerzej W. Benedek, M.C. Kettemann, Freedom of Expression and the Internet, Strasbourg 2014, s. 154 .

${ }^{46}$ Zob. Internet Freedom, Why it Matters, OSCE/The Representative on Freedom of the Media, Vienna 2012, s. 14.

${ }^{47}$ OSCE Joint Declaration on Freedom of Expression and the Internet, 1 June 2011.

${ }^{48}$ Wolne media na wschodzie w zagrożeniu. Relacja z corocznej konferencji OBWE poświęconej prawom człowieka,

http://www.obserwatorium.org/index.php?option=com_content\&view=article\&id=3956:-wolnemedia-na-wschodzie-w-zagroeniu-relacja-z-corocznej-konferencji-obwe-powiconej-prawomczowieka-\&catid=47:aktualnosciprog\&Itemid=66 (dostęp: 16.02.2015).

${ }^{49}$ Zob. From Traditional to Online Media: Best Practices and Perspectives, $14^{\text {th }}$ Central Asia Media Conference Ashgabat, Turkmenistan 5-6 July 2012, OSCE/ The Representative on Freedom of the Media, Vienna 2013, s. 14. 
jak Azerbejdżan czy Uzbekistan, pokazuje, jak łatwo wykorzystać infrastrukturę blokowania także do innych celów.

Analizując działalność urzędu Przedstawiciela ds. Wolności Mediów OBWE, można natrafić na przykłady sytuacji, gdy poszczególne państwa kwestionowały jego mandat do wstawiania się za represjonowanym blogerami czy dziennikarzami obywatelskimi działającymi w sieci, wskazując, że nie są oni pełnoprawnymi przedstawicielami prasy. Przedstawiciel stanowczo podkreślał, że uznaje, iż jego mandat obejmuje wolność wszelkich mediów, także Internetu. „Ze względu na rozwój technologii nie jest obecnie możliwe stworzenie uniwersalnej i wyczerpującej definicji dziennikarza. Ja nie chcę wdawać się zresztą w spór teoretyczny i mam zamiar stawać w obronie wszystkich, którzy mają w sobie pasję informowania opinii publicznej o sprawach ważnych społecznie, choćby publikowali jedynie na Twitterze"50 - mówiła Dunja Mijatović.

Internet, jak żadne inne medium, pozwala w sposób niemal nieograniczony wyrażać swoje poglądy, ideologie, sprzeciw przeciwko komuś lub czemuś. Przy tym wszystkim jest medium niezwykle egalitarnym, dając szanse wypowiedzi wykształconemu erudycie i prostemu człowiekowi. Pozwala on aktywizować nowe ruchy społeczne, krytyczne wobec istniejącego porządku społecznego, stając się nową formą protestu dla osób w jakikolwiek sposób zniewolonych ${ }^{51}$. Działania Przedstawiciela są również widoczne w dziedzinie mediów elektronicznych ${ }^{52}$. Nowe technologie bowiem wymagają nowego podejścia do ochrony wolności zobowiązań OBWE w zakresie mediów ${ }^{53}$.

Przedstawiciel podkreślał wielokrotnie ewolucję i znaczenie nowego rodzaju sprawozdawczości określanego mianem „otwartego dziennikarstwa” czy też „dziennikarstwa obywatelskiego”. Genezy jego rozwoju według Przedstawiciela należy upatrywać w rosnącej cyfryzacji społeczeństw. Wielki świat staje się mały, wiadomości są publikowane i omawiane w pozornie niekończącym się strumieniu stanowisk, pojawiają się tweety, komentarze w sieci. Rośnie rola serwisów społecznościowych. Termin „otwarte dziennikarstwo" odzwierciedla zatem fakt, że wolność poszukiwania, udostępniania i przekazywania informacji i idei nie jest już zarezerwowana wyłącznie dla nielicznych osób. Otwarte dziennikarstwo oddaje stały rozwój, w którym to czytelnicy tworzą narrację. Sformułowaniu „słowo jest wolne” nadano zatem nowy wydźwięk.

Przedstawiciel ds. Wolności Mediów jest również upoważniony do wydawania publicznych oświadczeń. Instrument ten ma posłużyć do uświadomienia wszystkim społeczeństwom zagrożeń, z jakimi borykać się muszą niezależne media. Uważa, że to jest to kluczowe w pomocy zarówno rządom, jak i obywatelom w rozwiązywaniu

\footnotetext{
${ }^{50}$ Ibidem.

${ }^{51}$ D. McQuail, Teoria komunikowania masowego, Warszawa 2007, s. 61.

${ }^{52}$ Szerzej Freedom of Expression on the Internet. A Study of Legal Provisions and Practices Related to Freedom of Expression, the Free Flow of Information and Media Pluralism on the Internet in OSCE Participating States, OSCE/The Representative on Freedom of the Media, Vienna 2012, Vienna 2012.

${ }^{53}$ Szerzej The Representative on Freedom of the Media, From traditional to Online Media: Best Practices and Perspectives, 14th Central Asia Media Conference Ashgabat, Turkmenistan 5-6 July 2012, Organization for Security and Co-operation in Europe 2013.
} 
problemów dotyczących wolności mediów. Interwencje Przedstawiciela mają być wsparciem w reformowaniu i dostosowaniu krajowego ustawodawstwa ${ }^{54}$.

Problematyka wolności mediów w państwach europejskich, niezależnie od położenia geograficznego i sytuacji ekonomicznej, stanowi temat niebywale delikatny, ale jest on ważny dla rozwoju danego społeczeństwa. Niewątpliwie poziom, na jakim funkcjonują media w danym społeczeństwie, jest także odzwierciedleniem stanu poszanowania praw i wolności człowieka. Dlatego też została utworzona funkcja przy OBWE dla Przedstawiciela ds. Wolności Mediów. Organ ten ma ostrzegać oraz przypominać państwom członkowskim o ich zobowiązaniach w tym zakresie, deklaracjach ${ }^{55}$ oraz oferować pomoc i wsparcie, gdy kraje te tego potrzebują. Wszystkie społeczeństwa powinny być uświadamiane, że wolność słowa ma również swoje granice. Dlatego rola Przedstawiciela ds. Wolności Mediów w systemie aksjologicznym OBWE wzrasta, gdy ujawniają się coraz to nowe zagrożenia dotyczące mediów, zwłaszcza te zagrażające ich wolności.

\section{LITERATURA}

[1] Access to Information and New Technologies, 12th Central Asia Media Conference Dushanbe, Tajikistan 25-26 May 2010, OSCE/The Representative on Freedom of the Media, Vienna 2012.

[2] Antpöhler C., Bogdandy A.V., Dickschen J., Hentrei S., Kottmann M., Smrkolj M., Reverse Solange - Protecting the essence of Fundamenta Rights Against EU Member States, „Common Market Law Review” 2012/2.

[3] Benedek W., Kettemann M.C., Freedom of Expression and the Internet, Strasbourg 2014.

[4] Biłgorajski A., Mowa nienawiści vs. Wolność słowa (głos w dyskusji), [w:] Mowa nienawiści a wolność słowa. Aspekty prawne i społeczne, red. A. Bodnar, A. Gliszczyńska-Grabias, R. Wieruszewski, M. Wyrzykowski, Warszawa 2010.

[5] Brogi E., Dobreva A., Parcu P.L., Freedom of the Media in Western Balkans, European Parliament, EESC, Brussels 2014.

[6] Commitments Freedom of the Media. Freedom of Expression, Free Flow of Information, Conference on Security and Co-operation in Europe (CSCE) and Organization for Security and Co-operation in Europe (OSCE), 1975-2012, OSCE/The Representative on Freedom of the Media, Vienna 2012.

[7] Commitments. Freedom of the Media. Freedom of the Expression. Free Flow of Information, Conference on Security and Co-operation in Europe (CSCE) and Organization for Security and Co-operation in Europe (OSCE), 1975-2012, wyd. 2, OSCE, Representative on Freedom of the Media, Vienna 2013.

[8] Fawn R., International Organizations and Internal Conditionality: Making Norms Matter, New York 2013.

\footnotetext{
${ }^{54}$ Zob. The Representative on Freedom of the Media, Ten Years for Media Freedom An OSCE Anniversary. Current and Forthcoming Challenges, Organization for Security and Co-operation in Europe 2008, s. 47-51.

${ }^{55}$ Szerzej A. Hulin, Joint Declarations of the Representatives of Intergovernmental Bodies to Protect Free Media and Expression, OSCE/The Representative on Freedom of the Media, Vienna 2013, s. 9-13.
} 
[9] Florczak A., Organizacje regionalne o charakterze ogólnym, [w:] Organizacje w stosunkach międzynarodowych. Istota - mechanizmy działania - zasięg, red. T. Łoś-Nowak, Wrocław 2009.

[10]Freedom of Expression on the Internet. A Study of Legal Provisions and Practices Related to Freedom of Expression, the Free Flow of Information and Media Pluralism on the Internet in OSCE Participating States, OSCE/The Representative on Freedom of the Media, Vienna 2012, Vienna 2012.

[11] From Traditional to Online Media: Best Practices and Perspectives, $14^{\text {th }}$ Central Asia Media Conference Ashgabat, Turkmenistan 5-6 July 2012, OSCE/The Representative on Freedom of the Media, Vienna 2013.

[12] Horsley W., Safety of Journalist Guidebook, wyd. 2, Office of the Representative on Freedom of the Media, Vienna 2014.

[13] Internet Freedom, Why it Matters, OSCE/The Representative on Freedom of the Media, Vienna 2012.

[14] Human Rights and a Changing Media Landscape, Strasbourg 2011.

[15] Jaskiernia A., Metody badawcze europejskich standardów demokratycznych $w$ obszarze mediów masowych, „Przegląd Europejski” 2011/1.

[16] Jaskiernia A., Rada Europy a problemy mediów masowych, Warszawa 2002.

[17] Journalist Education - Improvement of the Quality of Education and New Technologies, $6^{\text {th }}$ South Caucasus Media Conference, Tbilisi, Georgia, 19-20 November 2009, OSCE/The Representative on Freedom of the Media, Vienna 2010.

[18] Komorek E., Media Pluralism and European Law, Alphen aan der Rijn 2013.

[19] McQuail D., Teoria komunikowania masowego, Warszawa 2007.

[20] Medias and European Diversity, red. L. Soproni, I, Horga, Brussels 2012.

[21] Mijatović D., The Main Challenges of the OSCE Representative on Freedom of the Media, ,Security and Human Rights” 2013/3-4.

[22] Mik C., Media masowe w europejskim prawie wspólnotowym, Torun 1999.

[23] Mrozik K., Przedstawiciel ds. Wolności Mediów Organizacji Bezpieczeństwa i Wspótpracy w Europie, [w:] Efektywność mechanizmów ochrony praw człowieka Rady Europy, Unii Europejskiej i OBWE, t. I, red. J. Jaskiernia, Torun 2012.

[24] OSCE Joint Declaration on Freedom of Expression and the Internet, 1 June 2011.

[25] OSCE Safety of Journalists Guidebook, OSCE/The Representative on Freedom of the Media, Vienna 2011.

[26] Pasionek P., Demokracja a media, Lublin 2008.

[27] Price M.E., Free Expression, Globalism and the New Strategic Communication, New York 2015.

[28] Skowron J., Ocena niezależności funkcjonowania mediów w latach 2008-2011 przez Przedstawiciela do Spraw Wolności Mediów OBWE, [w:] Efektywność europejskiego systemu ochrony praw czlowieka, t. I: Efektywność mechanizmów ochrony praw człowieka Rady Europy, Unii Europejskiej $i$ OBWE, red. J. Jaskiernia, Torun 2012.

[29]The Online Media Self-Regulation Guidebook, OSCE/The Representative on Freedom of the Media, Vienna 2013.

[30] The Representative on Freedom of the Media, From traditional to Online Media: Best Practices and Perspectives, 14th Central Asia Media Conference Ashgabat, 
Turkmenistan 5-6 July 2012, Organization for Security and Co-operation in Europe 2013.

[31] The Representative on Freedom of the Media, Pluralism and Internet Governance, 13th Central Asia Media Conference Duszanbe, Tajikistan 29-30 Novembe 2011, Organization for Security and Co-operation in Europe 2012.

[32] The Representative on Freedom of the Media, The Impact of Media Concentration on Professional Journalist, OSCE, Vienna 2003.

[33] Wacks R., Privacy and the Media Freedom, Oxford 2013.

[34] Why Free Media Matters, OSCE/ The Representative on Freedom on the Media, Vienna 2012.

[35]Żur H., Systemy demokratyczne a informacja, „Wiadomości Statystyczne” $2003 / 1$.

\section{AXIOLOGY FREEDOM OF THE MEDIA IN THE LIGHT OF THE WORK OF THE OSCE HIGH REPRESENTATIVE ON FREEDOM OF THE MEDIA}

Freedom of the media, freedom of expression and the freedom in the transfer or information is one of the priorities of the OSCE. Therefore, the author of this article analyzes the courses of action created in 1997 OSCE Representative on Freedom of The Media. This institutions is a response to the observed increasing in many countries to purse the limitation of freedom and independence of the media.

The main function of the OSCE Representative on Freedom of the Media is to observe relevant media developments in OSCE participating States. Moreover very important function is to assist participating States by advocating and promoting full compliance with OSCE principles and commitments regarding freedom of expression and free media. He receives information on situation of the media from a variety of sources as participating OSCE States, media organizations and non-governmental organizations.

The Representative co-operates closely with the Permanent Council, the Participating States, the Office for Democratic Institutions and Human Rights, the High Commissioner on National Minorities, and, where appropriate, other OSCE bodies, as well as with national and international media associations.

The Representative on Freedom of the Media undertook various activities and participates in projects which are connected with freedom of expression and free media. $\mathrm{He}$ takes part in lectures or speeches that move topics such as freedom of the press, radio, television and the Internet. The Representative deals with topics related to the safety of journalists, freedom of expression and basic human rights.

The Representative on Freedom of the Media also takes voice in development of the law countries where situation called for his intervention.

Keywords: freedom of the media, the OSCE High Representative on Freedom of the Media, the safety of journalists

DOI:10.7862/rz.2015.hss.17

Przesłano do redakcji: maj 2015

Przyjęto do druku: lipiec 2015 